\title{
A NEW PULVINARIA FOUND ON ORCHIDS.
}

BY T. D. A. COCKERELL, N. M. AGR. EXP. STA.

\section{Pulvinaria brassice, n. sp.}

o scale rather like Lecanium hesperidum, elongate-oval, flattish, pale olive-brown, $2 \mathrm{I} / 2 \mathrm{~mm}$. long. Ovisac white, firm, elongate, parallelsided, distinctly longitudinally grooved, $8 \mathrm{~mm}$. long, 2 broad. Derm colourless, not tessellate. Margin with a double row of easily-deciduous, strong, usually large, blunt spines, which are, near the lateral and posterior clefts, more or less branched at their tips. Spines of lateral clefts in threes, one very long and large, two very short and small. Anal plates brown, longer than broad, their outer sides meeting at about a right angle. Each plate with three small spines at tip, and three large bristles on outer hind margin. Anogenital ring with six stout hairs. Rostral loop reaching to level of insertion of middle pair of legs. Antennæ 8-jointed ; 3 longest, but not greatly so. Formula $32(458) \times 67$. Two and 5 each with a long hair ; 8 with several long hairs. Legs ordinary; coxa more than half as long as trochanter + femur. Trochanter with a strong, but not very long, bristle. Claw short, stout, curved. Tarsal digitules long, moderately stout, distinctly knobbed. Digitules of claw extremely stout, gradually widening to the large knobs.

Hab. - On leaves of Brassia verrucosa, a native of Mexico, in greenhouse at Ottawa, Dec. I 5 th, I 894 (J. Fletcher). The actual plant was purchased from a New Jersey florist, and the insect has been found on no other in the house. It is quite a distinct and peculiar form of the type of $P$. camellice, but smaller, with a much narrower, ribbed ovisac. I regret that $\mathrm{I}$ have not seen the description of $P$. linearis, Targ., 1885 , found on Camellia japonica, but it is doubtless safe to assume that it cannot be that species.

\section{THE: USE OF MEGALOPYGE.}

BY A. R. GROTE, A. M., BREMEN, GERMANY.

In the able and original paper on "Evolution and Taxonomy," by my friend, Prof. Comstosk, published in 1893 , is a note, on page 103 , relating to the use of the generic title Megalopyge. The author says, referring to Berg's (not "Berge") articles on Argentine Lepidoptera: "This monograph seems to have been overiooked by American writers." This seems not quite correct. In Papilio, Vol. 3, 106-8, I have published (I 883) a review of these papers by C. Berg. I took, in the course of a lengthy 
review, the ground that Hubner's genus Megalopyge was a mixed genus, being proposed for two species, lanatu and nuda, and that there was no proof that these two species were congeneric. In the absence of such proof, it was not correct for Berg to designate lanata (and its structural allies) as either the type of or typical of Megalopyge. Under these circumstances, I preferred Harris's term Lagoa as a proper restriction of Hubner's genus for the type to which pyxidifera, opercularis and crispata belong. I did not know then, what seems to be the fact, that Lagoa was preoccupied and must be wholly rejected on this score. But then Pimela, Clem., I 860 , for the same type must be considered as the next available term for a restriction of Megalopyge. The matter stands thus: If lanata and $n u d a$ are congeneric, then Pimela falls as a synonym of Hubner's genus. If these two are not congeneric, then Clemens's term must be used for lanata and our North American species, as the first restriction of Hubner's genus, and Megalopyge must be left to the type nuda, a species quite unknown to me. As to this and related matters, I think I can refer the student to the paper in "Papilio," above cited, in which I drew the attention of American Lepidopterists quite fully to Berg's valuable writings.

\section{BOOK NOTICES.}

"The Classification of the Lepidoptera," by Vernon L. Kellogg, American Naturalist, Vol. XXIX, pp. $248-257$, plate XVII. (March, I895).

Mir. Kellogg reviews Prof.' Comstock's classification of the Lepidoptera especially in regard to the establishment of the sub-orders Jugatæ and Frenate (Evolution and Taxonomy), and shows how his own researches on the wing scales corroborate this division. He adds nothing essential to his former results in this direction (Kansas Univ. Quarterly, III., 45-39, r894), and so far it appears that the wing scales do not afford a basis for the subdivision of the Frenate. The new part of the present article consists of a consideration of the mode of specialization of the meso- and meta-thoracic segments, as effected by a cephalization of the powers of flight. The Jugatæare found to be in a generalized condition in this respect, but apparently not more so than certain Tineidæ; therefore, the result of this investigation is not a convincing support of Prof. Comstock's sub-orders, though it does show that the Hepialidæ belong low in the scale, as they are placed in Dr. Chapman's pupal classification. It is another argument against the old group of Bombyces.

Harrison G. DYar. 